\title{
Pelaksanaan Asesmen Risiko Jatuh di Rumah Sakit
}

\author{
Hirza Ainin Nur, Edi Dharmana, Agus Santoso \\ Universitas Diponegoro Semarang \\ JI. Prof. Soedarto, Tembalang, Kota Semarang, Jawa Tengah 50275, Indonesia \\ Email : hirza.aini23@gmail.com
}

\begin{abstract}
Abstrak
Pasien jatuh merupakan insiden jatuhnya pasien di rumah sakit yang paling mengkhawatirkan dan berdampak pada cedera bahkan kematian. Insiden pasien jatuh menempati urutan kedua kejadian tidak diharapkan setelah kesalahan pengobatan. Rumah Sakit sudah melakukan upaya untuk mengurangi insiden jatuh namun kenyataannya insiden jatuh masih terjadi. Data yang diperoleh dari Bulan Maret-September 2016 terdapat 6 kasus insiden pasien jatuh dari total 43 insiden keselamatan pasien. Hasil observsi menunjukkan sebagian besar program pencegahan jatuh yang belum dilakukan yaitu asesmen risiko jatuh. Asesmen risiko jatuh merupakan langkah awal untuk mencegah terjadinya jatuh pada pasien, apabila tidak dilakukan maka insiden jatuh akan terjadi. Penelitian ini bertujuan untuk mengeksplorasi pelaksanaan asesmen risiko jatuh yang dilakukan oleh perawat di ruang rawat inap rumah sakit. Metode penelitian yang digunakan yaitu riset kualitatif dengan pendekatan fenomenologi. Populasi yang digunakan yaitu perawat ruang rawat inap sejumlah 304 perawat. Pengambilan sampel dilakukan dengan teknik purposive sampling sebanyak 10 informan. Pengumpulan data menggunakan data primer dan sekunder. Data primer dilakukan secara indepth interview dengan wawancara semi terstruktur kepada semua informan. Data sekunder dilakukan dengan telaah dokumen yaitu SPO pencegahan risiko jatuh, buku panduan asesmen, dan status rekam medis pasien. Analisis data menggunakan model analisis Miles dan Huberman dengan mereduksi data, membuat data display, dan menarik kesimpulan. Hasil penelitian terdapat dua tema yaitu adanya pelatihan internal dan sosialisasi mempengaruhi pemahaman perawat terhadap pelaksanaan asesmen risiko jatuh baik asesmen awal risiko jatuh maupun asesmen ulang risiko jatuh dan pelaksanaan asesmen risiko jatuh dipengaruhi oleh adanya faktor penghambat dan pendukung, dimana kedua faktor tersebut mempengaruhi kepatuhan asesmen risiko jatuh yang dilakukan oleh perawat. Penelitian ini menunjukkan bahwa adanya pemahaman terkait asemen risiko jatuh tidak menjamin perawat patuh terhadap pelaksanaan asesmen risiko jatuh. Diharapkan adanya kerjasama antara manajemen rumah sakit, pokja pencegahan risiko jatuh, serta kepala ruang untuk senantiasa melakukan supervisi dan monitoring evaluasi terkait pelaksanaan asesmen risiko jatuh disertai dengan pemberian reward dan punishment yang jelas.
\end{abstract}

Kata Kunci: pelaksanaan asesmen risiko jatuh, perawat, rumah sakit

\section{The Implementation of Falls Risk Assessment InThe Hospital}

\begin{abstract}
Falls are the most worrying incidence of patients in the hospital and that have an impacton injury and even death. The incidence was second ranks of adverse event after medication errors. Hospitals are already making efforts to reduce the fall incident but in reality the incidence of falls still occurs. Data obtained from March to September 2016 have 6 cases of incident patients falling from a total of 43 patient safety incidents. The results of the observation show that most of the fall prevention programs that have not been done are falling risk assessments. Fall risk assessment is the first step to prevent the occurrence of falls in the patient, if not done then the incident will occur. This study aims to explore the implementation of falls risk assessment conducted by nurses in the hospital wards. The research method using qualitative research with phenomenology approach. The population used is inpatient ward nurses as many as 304 nurses. The sample used by purposive sampling technique with 10 informants. Data collection using primary and secondary data. Primary data obtained by indepth interview with semi structured interview to all informants. Secondary data was used document review
\end{abstract}


of SOP prevention of fall risk, assessment protocol, and patient's medical record status. Data analysis used Miles and Huberman analysis model by reducing data, making display data, and drawing conclusions. The results of the research are two themes that are the existence of internal training and socialization affects the nurse's understanding of the implementation of falls risk assessment both initial of falls risk assessment and re-assessment of falls risk and implementation of falls risk assessment influenced by the inhibiting and supporting factors, both of these factors affect compliance of falls risk assessment conducted by the nurse. This study suggests that the understanding of fall risk assessment does not guarantee the nurse to always adhere to the implementation of fall risk assessment. It is expected that there will be cooperation between hospital management, working group prevention of falls risk, and head of ward to always supervise and monitor evaluation related to implementation of falls risk assessment along with giving reward and punishment.

Keywords: implementation of falls risk assessment, nurse, hospital

Info Artikel:

Artikel dikirim pada 04 Juli 2017

Artikel direvisi pada 22 September 2017

Artikel diterima pada 25 September 2017

DOI: http://dx.doi.org/10.21927/jnki.2017.5(2).123-133

\section{PENDAHULUAN}

Pasien jatuh diartikan sebagai insiden di rumah sakit yang sering terjadi yang dapat mengakibatkan cedera serius bahkan kematian. Pencegahan risiko jatuh merupakan sasaran keselamatan pasien keenam dan penting untuk dilakukan karena pasien jatuh menjadi suatu insiden yang sangat mengkhawatirkan pada seluruh pasien rawat inap dan menjadi adverse event kedua terbanyak dalam perawatan kesehatan setelah kesalahan pengobatan(1-3).

Insiden pasien jatuh di rumah sakit Amerika Serikat dilaporkan sebanyak 700.000 sampai 1.000 .000 orang mengalami jatuh setiap tahun (4). Laporan dari rumah sakit dan unit kesehatan mental di Inggris pada tahun 2011 sebanyak 282.000 pasien jatuh setiap tahun, dimana 840 pasien mengalami patah tulang pinggul, 550 pasien mengalami fraktur, dan 30 pasien mengalami cidera intra kranial (5).

Di Indonesia data terkait insiden pasien jatuh berdasarkan laporan dari kongres XII PERSI pada tahun 2012 menunjukan bahwa insiden pasien jatuh termasuk ke dalam tiga besar insiden medis rumah sakit dan menduduki peringkat kedua setelah medicine error. Data dari laporan tersebut memperlihatkan bahwa sebanyak 34 kasus atau setara $14 \%$ insiden jatuh di Rumah Sakit di Indonesia (6). Hal ini membuktikan bahwa insiden pasien jatuh masih tinggi dan masih jauh dari standar akreditasi yang menyatakan untuk insiden pasien jatuh diharapkan tidak terjadi di rumah sakit atau $0 \%$ kejadian (1). Melihat begitu banyaknya insiden pasien jatuh dan dampak yang ditimbulkan, maka Joint Commission
International $(\mathrm{JCl})$ dan Komite Akreditasi Rumah Sakit (KARS) memasukkan pencegahan risiko jatuh sebagai sasaran keselamatan pasien dan menjadi salah satu penilaian akreditasi $(1,2)$.

Wawancara yang dilakukan terhadap perawat RSUD RA. Kartini Jepara menyatakan bahwa Di RSUD RA Kartini Jepara sudah dilakukan pelatihan internal dan sosialisasi terkait keselamatan pasien, sudah dibentuk pokja pencegahan risiko jatuh, sudah ada format asesmen dan intervensi pencegahan risiko jatuh, dan sudah mempunyai SPO terkait pencegahan risiko jatuh.

Adanya upaya-upaya tersebut digambarkan perawat mempunyai kemampuan yang baik terkait pencegahan risiko jatuh. Namun faktanya insiden jatuh di rumah sakit masih terjadi. Data yang diperoleh dari Bulan Maret-September 2016 terdapat 6 kasus insiden pasien jatuh dari total 43 insiden keselamatan pasien.

Hasil observasi menunjukkan bahwa sebagian besar program pencegahan risiko jatuh yang belum optimal yaitu berkaitan dengan asesmen risiko jatuh yang dilakukan oleh perawat. Padahal asesmen risiko jatuh merupakan langkah awal dari program pencegahan jatuh, apabila tidak dilakukan maka perawat tidak dapat melakukan intervensi pencegahan risiko jatuh dan hal ini dapat mengakibatkan terjadinya insiden pasien jatuh di rumah sakit.

Penelitian ini bertujuan untuk mengeksplorasi pelaksanaan asesmen risiko jatuh yang dilakukan oleh perawat di ruang rawat inap RSUD RA. Kartini Jepara. 


\section{BAHAN DAN METODE}

Penelitian ini menggunakan metode kualitatif dengan pendekatan fenomenologi. Populasi yang digunakan pada penelitian ini yaitu perawat ruang rawat inap RSUD RA. Kartini Jepara sebanyak 304 perawat. Pengambilan sampel menggunakan non probability sampling dengan teknik purposive sampling. Kriteria inklusi yang digunakan perawat yang sudah bekerja selama $>3$ tahun. Jumlah informan utama yang digunakan sebanyak 6 informan dari tiga ruang rawat inap: bangsal anak, unit stroke, dan bangsal psikiatrik. Dari masingmasing ruangan tersebut diambil 2 perawat. Jumlah informan triangulasi sebanyak 3 orang kepala ruang dari masing-masing ruangan dan 1 orang pokja pencegahan risiko jatuh. Jadi total informan yang digunakan yaitu sebanyak 10 orang.

Pengumpulan data yang dilakukan peneliti dengan menggunakan data primer dan data sekunder. Data primer dilakukan dengan wawancara semi terstruktur secara indept interview selama 40-60 menit yang berkaitan dengan pemahaman, faktor penghambat dan pendukung, upaya untuk mengatasi hambatan, serta harapan untuk mengoptimalkan pelaksanaan asesmen risiko jatuh. Data sekunder dilakukan dengan telaah kelengkapan dokumen tentang asesmen risiko jatuh mulai dari SPO, format, buku panduan, serta status rekam medis pasien yang berkaitan dengan asesmen risiko jatuh.

Guna mengetahui keabsahan data dillakukan uji kredibilitas, transferbilitas, dependabilitas, dan konfirmabilitas. Kredibilitas/derajat kebenaran data diperoleh melalui triangulasi sumber, teknik, dan teori. Triangulasi sumber yang dilakukan yaitu dengan melakukan wawancara kepada informan triangulasi sebanyak 4 orang (3 orang merupakan kepala ruang masing-masing ruangan yang digunakan, dan 1 orang dari pokja pencegahan risiko jatuh). Triangulasi teknik dengan cara membandingkan data yang diperoleh dengan melakukan pengecekan terhadap dokumen yang berkaitan dengan asesmen risiko jatuh (SPO, format, buku panduan, dan status rekam medis pasien). Triangulasi teori dilakukan dengan cara membandingkan data yang diperoleh dengan perspektif teori yang ada baik dari buku maupun jurnal. Transferbilitas dilakukan dengan cara peneliti membuat gambaran dan pemahaman yang jelas tentang pelaksanaan asesmen risiko jatuh sehingga informan dapat mengevaluasi kesesuain data tersebut. Uji dependabilitas dan konfirmabilitas dilakukan secara bersamaan melalui auditing (pemeriksaan) dengan menguji hasil penelitian dikaitkan dengan proses yang dilakukan. Analisis data menggunakan model analisis Miles dan Huberman. Reduksi data dengan cara mencari kata kunci, membuat kategori, dan melakukan pengkodean. Selanjutnya dibuat data display dengan membuat hubungan antar kategori dan tema, kemudian terakhir menarik kesimpulan.

\section{HASIL DAN BAHASAN}

Pada penelitian ini dihasilkan 2 tema yang merupakan hubungan dari beberapa kategori yang saling berkaitan yaitu tentang pelatihan internal, sosialisasi, pemahaman asesmen risiko jatuh, asesmen awal risiko jatuh, asesmen ulang risiko jatuh, pelaksanaan asesmen risiko jatuh, faktor penghambat, faktor pendukung, dan kepatuhan asesmen risiko jatuh. Hubungan antar kategori dan tema tersebut disajikan pada Gambar 1.

Adapun dari Gambar 1 tersebut didapatkan tema sebagai berikut:

1. Adanya pelatihan internal dan sosialisasi mempengaruhi pemahaman perawat terhadap pelaksanaan asesmen risiko jatuh baik asesmen awal risiko jatuh maupun asesmen ulang risiko jatuh.

2. Pelaksanaan asesmen risiko jatuh dipengaruhi oleh adanya faktor penghambat dan pendukung, dimana kedua faktor tersebut mempengaruhi kepatuhan asesmen risiko jatuh yang dilakukan oleh perawat.

Tema 1: Adanya pelatihan internal dan sosialisasi mempengaruhi pemahaman perawat terhadap pelaksanaan asesmen risiko jatuh baik asesmen awal risiko jatuh maupun asesmen ulang risiko jatuh

Pemahaman perawat tentang pelaksanaan asesmen risiko jatuh diperoleh melalui pelatihan internal dan sosialisasi yang dilakukan oleh rumah sakit baik itu dari manajemen rumah sakit maupun dari pokja yang bersangkutan.

\section{Pelatihan Internal}

Pelatihan internal atau in house training merupakan suatu program pelatihan yang diselenggarakan oleh rumah sakit dengan menggunakan tempat training, peralatan training, menentukan peserta dan dengan mendatangkan trainer sendiri (7). Pelatihan internal 


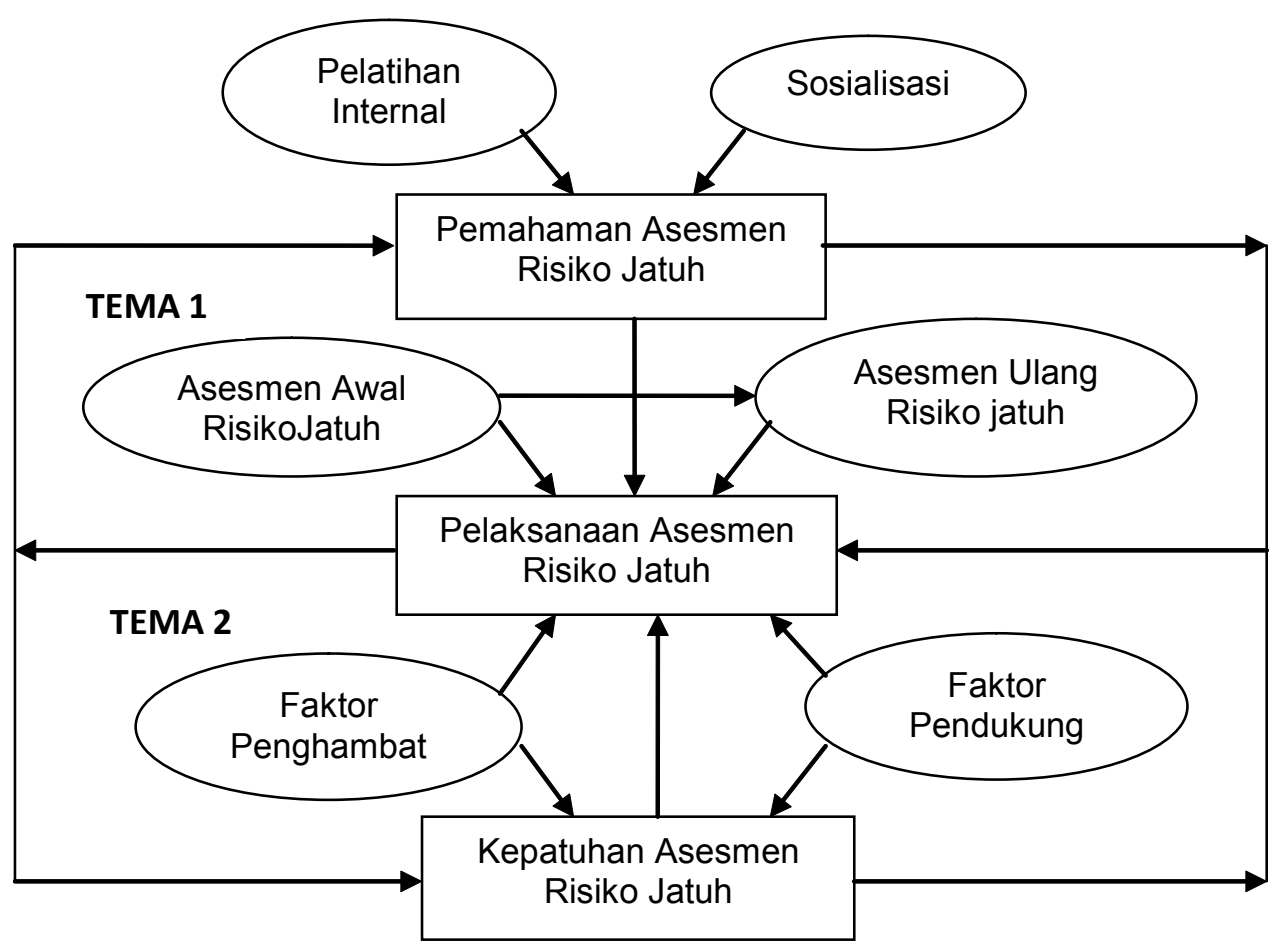

Gambar 1. Hubungan antar Kategori dan Tema

yang dilakukan di RSUD RA. Kartini Jepara yaitu berkaitan dengan seluruh aspek penilaian akreditasi rumah sakit yang salah satunya yaitu asesmen risiko jatuh. Berikut adalah beberapa transkrip wawancara dengan informan:

“....lya sudah ada pelatihan internalnya..... semua perawat wajib.... Termasuk risiko jatuh itu nanti dijelaskan dan diajari...." (11)

“....Kita semua sudah ikut pelatihan di aula.... ada status baru yang harus diisi cara pengisiannya gini gini gini...." (14)

“....lya ada itu mbak pelatihannya untuk semua perawat....Ada sertifikatnya ox mbak.... Itu ya pengenalan, sama caranya juga diajari....Risiko jatuh itu apa, formatnya apa, caranya gini gini gini...." ( I5)

"....Ada itu pelatihan semua perawat di aula.... Ada sertifikatnya...." (I6)

"....lya ada pelatihan.... Semua perawat... Pengenalan asesmen risiko jatuh, format, isinya apa saja...." (T2)

"....Ada pelatihannya untuk semua perawat.... Pencegahan jatuh itu apa aja, formatnya apa, caranya itu diajari...." (T3)

Adanya kesesuaian antara informan utama dan triangulasi menunjukkan bahwa di RSUD RA. Kartini Jepara memang sudah pernah dilakukan pelatihan internal berkaitan dengan sasaran keselamatan pasien yang salah satunya adalah pencegahan risiko jatuh. Penelitian ini sesuai dengan penelitian yang dilakukan oleh Yulia yaitu ada pengaruh pelatihan keselamatan pasien terhadap pemahaman perawat pelaksana mengenai penerapan keselamatan pasien dimana terdapat perbedaan yang signifikan antara sebelum dan sesudah dilakukan pelatihan (8).

\section{Sosialisasi}

Sosialisasi disebut sebagai proses belajar yang dialami seseorang untuk memperoleh pengetahuan, ketrampilan, nilai-nilai dan norma-norma dalam kehidupan bermasyarakat. Sosialisasi yang dilakukan di RSUD RA Kartini jepara bertujuan supaya perawat mempunyai ketrampilan dan kebiasaan dalam melaksanakan asesmen risiko jatuh dari kebiasaan tersebut diharapkan perawat dapat membudayakan keselamatan pasien (9). Adapun wawancara dengan informan adalah sebagai berikut:

$$
\begin{aligned}
& \text { “...Di ruangan-ruangan mereka pokjanya } \\
& \text { pada roadshow.... Mempraktikan sebelum } \\
& \text { ada catatan medisnya mereka pada } \\
& \text { mensosialisasikan.... Praktiknya dalam } \\
& \text { artian pengisian ini mbak asesmennya, } \\
& \text { terus juga SPO-SPO....” (I1) } \\
& \text { “...Sosialisasinya kemarin sudah ada } \\
& \text { semua.... Itu per ruangan-ruangan, jadi } \\
& \text { pokjanya keliling.... Itu nanti dipraktikan }
\end{aligned}
$$


cara mengisinya.... Memakai semacam contoh kasus dari pasien terus diisi...." (I2)

“... Setiap format dan SPO sudah di sosialisasi sama pokjanya.... Itu nanti dia datang muter setiap ruangan.... Dijelaskan dan dipraktikkan...." (I3) "....Pokjanya datang ke ruangan menjelaskan SPO kemudian disosialisasikan.... Selain SPO ya blangko asesmennya jadi mereka kan ngajari cara-caranya gimana langsung praktik...." (I5)

"....Pokja itu sosialisasi setiap mengeluarkan SPO.... Disosialisaikan di masing-masing ruangan.... Menjelaskan SPO dan pengisian blangko asesmennya...." (T2)

“....Pokja itu kan sosialisasi masalah ini kayak SPO-SPO.... Pokja keliling, sosialisasi format dan SPO.... Mereka menjelaskan dan mempraktikan cara pengisiannya...." (T3).

Dari hasil penelitian didapatkan bahwa pokja pencegahan risiko jatuh sudah melakukan sosialisasi di setiap ruangan rawat inap mengenai format dan SPO asesmen risiko jatuh. Cara sosialisasi yang dilakukan dengan menjelasakan dan mempraktikan SPO dan format asesmen risiko jatuh tersebut. Sosialisasi yang dilakukan di RSUD RA Kartini Jepara merupakan salah satu strategi manajemen untuk meningkatkan pemahaman dan ketrampilan perawat. Pemberian soialisasi ini dilakukan secara berulang-ulang supaya perawat mempunyai pemahaman dan ketrampilan asesmen risiko jatuh dengan benar dan tepat.

\section{Pemahaman Asesmen Risiko Jatuh}

Pemahaman adalah kemampuan seseorang untuk memahami suatu pengetahuan yang diterimanya. Pemahaman asesmen risiko jatuh diartikan sebagai kemampuan perawat untuk memahami dan mempelajari dengan benar terkait asesmen risiko jatuh. Pemahaman terhadap pengetahuan merupakan aspek kognitif dari seseorang. Perawat membutuhkan pemahaman yang lebih tentang program pencegahan risiko jatuh. Ketidaktahuan perawat tentang program pencegahan risiko jatuh inilah yang dapat mengakibatkan perawat tidak melaksanakan program pencegahan risiko jatuh tersebut yang salah satunya yaitu pelaksanaan asesmen risiko jatuh (10). Berikut adalah transkrip wawancara informan:
"....Asesmen pasien risiko jatuh di unit stroke menggunakan skala morse itu terdiri dari riwayat jatuh, status mental, terpasang infus tidaknya, sama diagnosa sekunder.... Kriterianya $0-24$ tanpa risiko jatuh, 25 - 50 risiko jatuhg sedang, kalau $>51$ sudah risiko tinggi.... Ini tinggal dicentang-centang terus dijumlahkan.... Format mudah dipahami.... Pengenalan tanda-tanda bahaya risiko jatuh" (I2)

"....Gangguan psikotropik pakainya edmonson.... Jadi dilihat dari usianya, status mentalnya, cara $B A B$ dan $B A K$, riwayat obat-obatannya, diagnosanya, masalah keseimbangan tubuh atau tidak, kemudian nutrisi, apakah dia tidurnya cukup atau tidak. Jadi nanti kita nilai.... Kita jumlahkan.... Kalau nilainya $>90$ berarti berisiko jatuh, kalau kurang tidak berisiko.... Itu nanti ada intervensinya sendiri-sendiri baik yang berisiko dan tidak berisiko...." (I3)

"....Di sini menggunakan humpty dumpty untuk anak-anak. Itu yang dikaji ada umur, jenis kelamin, diagnosa, gangguan kognitif, faktor lingkungan, respon terhadap pembadahan, sedasi dan anestesi, dan penggunaan obatobatan. Itu setiap pengkajian ada skor masing-masing tinggal kita pilih sesuai keadaan pasien kemudian ditotal skornya baru diketahui risiko tinggi atau rendah.... Setelah itu ke intervensinya. Intervensinya juga ada sendiri-sendiri baik yang risiko rendah dan risiko tinggi...." (I5)

"....Itu ada blangko asesmennya masing-masing.... Untuk humpty dumpty anak-anak, dewasa pakainya morse, psikiatrik memakai edmonson.... Itu nanti setiap pengkajian ada pilihan masingmasing dan skor masing-masing tinggal dicentang sesuai keadaan pasien dan dijumlahkan.... Kalau sudah dikategorikan tanpa risiko, risiko rendah, atau risiko tinggi...." (T4)

Berdasarkan wawancara dengan informan didapatkan bahwa di ruang rawat inap RSUD RA Kartini Jepara menggunakan 3 format asesmen risiko jatuh yaitu humpty dumpty untuk anak-anak, morse untuk dewasa, dan edmonson untuk pasien psikiatrik. Semua perawat di ruangan sudah memahami dari masing-masing asesmen risiko jatuh tersebut. Sejalan dengan telaah dokumen yang telah didapatkan bahwa untuk di ruang unit stroke terdapat format morse, ruang anak-anak terdapat format humpty dumpty, dan ruang psikiatrik terdapat format edmonson. 


\section{Asesmen Awal Risiko Jatuh}

Asesmen awal risiko jatuh merupakan serangkaian proses asesmen risiko jatuh yang berlangsung saat pasien masuk rawat inap untuk dilakukan pemeriksaan secara sistematis untuk mengidentifikasi masalah keperawatan pada pasien dalam kurun waktu 24 jam (11). Perawat melaksanakan asesmen awal risiko jatuh ketika ada pasien baru yang masuk ruang rawat inap. Adapun wawancara dengan informan sebagai berikut:

“....Kalau ada pasien baru kita asesmen awal waktunya 24 jam.... Dari pasien masuk.... (I1)

“....Pada saat pasien dari IGD, setelah serah terima.... Kita kaji pengkajian asesmen risiko jatuh yang ada di status.... Dalam 24 jam pertama" (I3)

"....Pasien masuk pasien datang sekalian kita penjelasan edukasi ke keluarga.... Jadi sekalian kita asesmen...." (14)

“....Iya pasien baru dari IGD atau poli... Sudah sampai sini nanti kita serah terima.... Sampai sini diasesmen lagi pakainya asesmen awal keperawatan dalam waktu 24 jam..." (I5)

"....Pada saat pasien pertama kali masuk datang.... Mengkaji asesmen awal keperawatan dilakukan 24 jam pertama termasuk asesmen pasien risiko jatuh...." (T2)

“....Pasien sampai di ruangan langsung begitu kita operan.... Ada asesmen awal rawat inap termasuk asesmen risiko jatuh.... Dilakukan 24 jam pertama... ."(T4)

Hasil wawancara di atas menunjukkan bahwa asesmen awal risiko jatuh rawat inap dimulai ketika pasien baru datang ke ruangan dari IGD maupun poli yang kemudian dilakuakan asesmen awal keperawatan rawat inap dalam waktu 24 jam pertama. Hal ini sesuai dengan hasil telaah dokumen panduan asesmen pasien yang dilakukan peneliti yang menyatakan bahwa asesmen awal pasien rawat inap dilakukan 24 jam pertama sejak pasien masuk ruang rawat.

\section{Asesmen Ulang Risiko Jatuh}

Asesmen ulang risiko jatuh diartikan sebagai proses asesmen yang dilakukan perawat selama transfer atau perawatan terhadap semua pasien, untuk mengidentifikasi adanya perubahan pada kondisi pasien, berupa perburukan/perbaikan kondisi (12). Perawat melaksanakan asesmen ulang risiko jatuh ketika ada indikasi-indikasi tertentu pada pasien. Kutipan wawancara dengan infroman sebagai berikut:

“....Untuk asesmen ulang dilakukan pada kondisi tertentu.... Pas transfer pasien, kemudian adanya perubahan kondisi, sama kalau pas pasien mengalamijatuh.... Monitoringnya digunakan kalau risiko tinggi diasesmen tiap shift... kalau rendah intervensi per hari,,,," (I2)

"....Asesmen ulang biasanya ada tanggaltanggalnya.... Lembar monitoring risiko jatuhnya terutama untuk pasien yang berisiko jatuh....dilakukan asesmen ulang lagi itu biasanya pasien mengalami perubahan kondisi kesehatannya ataupun kesadarannya.... Pasien transfer ke ruangan... Setelah pasien mengalami jatuh juga dilakukan asesmen ulang...." (I3)

“....Kalau asesmen ulang itu ada indikasinya.... Saat ada perubahan kondisi pasien, saat transfer pasien, setelah pasien terjadi jatuh.... Pasien berisiko tinggi jatuh diasesmen lagi di lembar monitoring...." (I6)

"....Mengalami perubahan kondisi, kemudian apabila ada kejadian jatuh, apabila pindah ke bangsal atau transfer pasien.... Itu risiko tinggi dilakukan skoring setiap shift dilembar monitoring kalau yang rendah intervensi per hari...." (T4)

Wawancara di atas menunjukkan bahwa asesmen ulang risiko jatuh dilakukan dengan kriteria tertentu meliputi: adanya transfer pasien ke ruangan, adanya perubahan kondisi pada pasien, setelah pasien mengalami jatuh, dan monitoring asesmen risiko jatuh setiap shift bila pasien berisiko tinggi dan per hari untuk risiko rendah. Hal ini juga sesuai dengan hasil telaah dokumen SPO asesmen ulang risiko jatuh yang menyatakan bahwa lakukan asesmen ulang risiko jatuh kepada pasien pada saat transfer ke bagian lain, adanya perubahan kondisi pasien, dan adanya kejadian jatuh pada pasien. Lakukan intervensi setiap sift untuk skor tinggi, dan intervensi per hari untuk skor rendah.

\section{Pelaksanaan Asesmen Risiko Jatuh}

Pelaksanaan asesmen risiko jatuh dilakukan dengan mewawancarai keluarga pasien. Ada beberapa pilihan item dari asesmen risiko jatuh 
yang harus ditanyakan kepada keluarga pasien yang tentunya tidak dapat dilihat secara langsung oleh perawat misalnya item riwayat jatuh pasien (pada skala morse, humpty dumpty, edmonson), item asupan nutrisi terakhir yang dikonsumsi pasien serta item kebutuhan istirahat dan tidur pasien pada skala Edmonson. Perawat melaksanakan asesmen risiko jatuh dengan cara mencentang item yang sudah disediakan di format asesmen. Berikut ini adalah transkrip wawancara dengan informan:

“....Pelaksanaannya diterapkan kepada semua pasien.... Bisa dilihat di status.... tinggal dicentang-centang... Wawancara dengan keluarga.... Langkah-langkah pelaksanaan mekanismenya itu sama...." (I2)

"....Pengisian asesmen risiko jatuh ada wawancara dengan keluarga...." (I3)

"....Pelaksanaan asesmen itu wawancara ke keluarga juga.... Asemen itu kan ada macam-macam jadi itu sekalian dilakukan.... Untuk langkah-langkah sama...." (I5)

"....lya kita wawancara ke keluarga bawa status ke pasien...." (T3)

Hasil penelitian menunjukkan bahwa pelaksanaan asesmen risiko jatuh dilakukan secara bersamaan dengan asesmen keperawatan yang lainnya. Pelaksanaan asesmen ulang risiko jatuh mekanisme dan langkah-langkahnya sama dengan asesmen awal risiko jatuh yang membedakan adalah indikasi atau kriteria pasien untuk dilakukan asesmen ulang.

Pemahaman dan pengetahuan asesmen risiko jatuh yang dilakukan oleh perawat di rumah sakit diperoleh melalui pelatihan internal dan sosialisasi. Dari proses pelatihan dan sosialisasi tersebut perawat mengerti dan memahami apa itu asesmen risiko jatuh, apa saja formatnya dan bagaimana cara mengisinya. Ketika perawat sudah paham betapa pentingnya asesmen risiko jatuh maka hal ini akan berdampak pada perilaku pelaksanaan asesmen risiko jatuh yang dilakukan.

Penelitian yang dilakukan oleh Budiono menyatakan bahwa faktor yang dapat meningkatkan ketrampilan petugas melakukan skrining risiko jatuh yaitu dengan adanya pelatihan dan sosialisasi terkait manajemen risiko jatuh (13). Hal ini didukung oleh pendapat Budioro yang menyatakan bahwa salah satu dari bentuk perubahan perilaku yaitu direkayasa melalui proses pendidikan, penyuluhan, pelatihan, dan bentuk proses belajar mengajar lainnya. Perubahan perilaku ini terbentuk secara sadar dan terencana melalui berbagai macam proses belajar mengajar yang diupayakan untuk merubah perilaku sebelumnya menjadi bentuk perilaku yang diinginkan (14).

Green berpendapat bahwa pengetahuan merupakan faktor predisposisi untuk merubah perilaku seseorang (15). Sedangkan Notoatmodjo mengungkapkan bahwa pengetahuan merupakan modal utama untuk meperoleh ketrampilan dan sikap (9). Hal ini sejalan dengan wawancara mendalam kepada informan bahwa semua informan menyatakan mereka mengetahui bagaimana pelaksanaan asesmen risiko jatuh dan asesmen risiko jatuh wajib untuk dilakukan. Maka diharapkan dengan memiliki pengetahuan dan pemahaman yang baik perawat patuh dalam melaksanakan asesmen risiko jatuh.

Tema 2: Pelaksanaan asesmen risiko jatuh dipengaruhi oleh adanya faktor penghambat dan pendukung, dimana kedua faktor tersebut mempengaruhi kepatuhan asesmen risiko jatuh yang dilakukan oleh perawat

Perawat dalam melaksanakan asesmen risiko jatuh dipengaruhi oleh faktor penghambat dan pendukung. Adanya kedua faktor tersebut dapat mempengaruhi kepatuhan perawat untuk melaksankanakan asesmen risiko jatuh.

\section{Faktor Penghambat}

Faktor penghambat merupakan kondisi yang dapat menghambat suatu kegiatan. Pada pelaksanaan asesmen risiko jatuh faktor penghambat diartikan sebagai kondisi-kondisi yang dapat menghambat pelaksanaan asesmen risiko jatuh, adanya kondisi tersebut dapat berpengaruh sedikit atau bahkan dapat menghentikan pelaksanaan suatu kegiatan. Kutipan wawancara dengan informan adalah sebagai berikut:

“.... Kondisi pasien kadang ada yang ngamuk, tidak stabil, ada juga visit dokter.... Sering kasus dapat pasien langsung 3, kemudian masih ada tindakan, kemudian kadang yang nganter bukan keluarga terdekat, masih kayak gitu tidak tercover.... Kalau tidak tercover kita operkan ke shift selanjutnya.... Pasien banyak yang harus diawasi, tindakan banyak terus kemudian kita harus melakukan asesmen lanjutan yang 
banyak jadi kayak beban kerja.... Belum ada reward, kita pengennya pekerjaan kita dihargai....kalau tidak dilakukan ya ditegur.... Supervisi dari pokja juga kurang...." (I1)

“....Kalau kendala ada SDM yang kurang memadai, pas beban kerja yang banyak dan tinggi, atau mungkin ada kondisi pasien yang berubah secara mendadak mungkin ada perubahan GCS, kejang.... Itu pengkajiannya belum bisa dilakukan tapi setelah shift kita operkan.... Rewardnya nggak ada kalo punishment ditegur.... Untuk supervisi asesor internal 3 bulan sekali itu semua aspek untuk akreditasi...." (I2)

"....Tergantung banyaknya kerjaan di sini apa nggak ya mbak, kadang pekerjaan banyak terus kondisi pasiennya banyak yang jelek sampai lupa, pasien banyak pengawasan.... Perawat juga dibebani buat rekening pasien kalau shift siang sama malam jadi nambah pekerjaan.... Reward untuk pelaksanaan asesmen secara langsung nggak ada, punishmentnya ya diingatkan, diopyaki.... Supervisi pokjanya keliatane cuma ambil blangko nggak sampe ke pelaksanaan jadi saya rasa juga kurang...." (I5)

".... Kendalanya untuk monitoring yang kadang diisi kadang tidak... biasanya keluarga tidak ada padahal kalau pasien baru harus general consent.... Kalau pasien penuh jelek semua ya sibuk banget, apalagi kalau harus suction berkala, atau ada yang bagging itu nggak bisa ditinggal.... Apalagi sekarang perawat dibebani merekening sampai pasien keluar.... Rewardnya nggak ada punishment ya ditegur.... Pokjanya itu selain selain nyerahin blangko sama ambil saya kira supervisinya kurang...." (T2)

“.... Kendalanya untuk ruang BPJS 1 ruang 8 pasien dan kapasitasnya 32 pasien kalau pasien full tidak sebanding jumlah pasien dan perawat apalagi kalau pasien yang butuh pengawasan.... Perawat bekerja multitalenta harus bisa semua mengambil obat, mengantar pasien, menggantikan tugas administrasi.... Supervisi pokja per bulan itu ambil blangko kalau ada masalah lapor ke PMKP.... Kalau asesor internal juga ada 3 bulan sekali tapi kebanyakan ke persiapan akreditasi...." (T4)

Dari hasil transkrip wawancara semua informan analisis peneliti terkait faktor penghambat pelaksanaan asesmen risiko jatuh yaitu faktor kondisi pasien (pasien berontak; pasien tidak stabil; pasien ngamuk; perubahan GCS; kejang), faktor keluarga yaitu tidak adanya keluarga pasien, faktor perawat (kesibukan perawat; beban kerja yang tinggi; SDM yang kurang memadai; pasien penuh dan banyak pengawasan), faktor kepemimpinan dan manajemen (kurangnya supervisi, kurangnya reward dan punishment)

\section{Faktor Pendukung}

Faktor pendukung merupakan kondisi yang dapat mendukung terlaksananya suatu kegiatan. Tanpa adanya faktor pendukung, pelaksanaan asesmen risiko jatuh di rumah sakit tidak akan terlaksana. Berikut ini adalah beberapa transkrip wawancara dengan informan:

“....Formatnya untuk di rawat inap ada 2 itu ada yang di asesmen awal rawat inap sama asesmen lanjutan atau monitoring.... Format mudah dipahami ada penjelasannya, tinggal centang-centang.... SPO ada sendiri yang asesmen awal sama asesmen ulang.... Motivasinya dari kepala ruang itu biasanya ngopyaki diingatkan kalo ada.... Diperlukan kerjasama, kalau bekerja sesuai prosedur, target, ada kepuasan, jadi motivasi tersendiri....." (I1)

"....Formatnya itu monitoring ada sendiri yang asesmen awal keperawatan juga ada sendiri. formatnya mudah dipahami, sudah ada nilai-nilainya, tinggal kasih tanda.... SPO juga sudah ada sendirisendiri semua penjelasan ada di SPO.... Motivasi kita saling mendukung, dan saling membantu...." (I2)

"....Formatnya sudah bisa semua, cukup mudah, tidak rumit. Kalau disini ada di asesmen IRNA, sama monitoring, jadi untuk awal dan ulang beda-beda.... SPO ada, asesmen awal sendiri, asesmen ulang sendiri... Termotivasi jika diingatkan...." (I5)

"Selama ini kok difasilitasi ya mbak.... SPO dan formatnya ada.... Saya menekankan kebersamaan ya mbak.... Kerjasama semua, tanggungjawab masing-masing, saling melengkapi.... Kalau ada yang kurang diingatkan...." (T1)

“.... Untuk format yang awal dan ulang sama isinya cuma lembarannya beda... mudah dipahami... SPO ada sendiri, SPO asesmen awal sendiri, SPO asesmen ulang, sama SPO pasien jatuh dengan 
atau tanpa cidera.... Perawatnya dilihat dari kerjasama tim bagus.... Kalau ada yang kurang diberi pengarahan, ditegur...." (T2)

Hasil wawancara informan menunjukkan bahwa faktor pendukung dari pelaksanaan asesmen risiko jatuh yaitu terkait dengan motivasi (baik sesama rekan kerja maupun kepala ruang) dan sarana prasarana (baik dari format asesmen maupun SPO). Hal ini sesuai dengan telaah kelengkapan dokumen di ruangan yang menunjukkan bahwa di ruangan terdapat format asesmen yang berbeda antara asesmen awal rawat inap termasuk asesmen risiko jatuh dan asesmen ulang risiko jatuh, serta terdapat berbagai SPO yang mendukung mulai dari SPO asesmen pasien, SPO asesmen awal risiko jatuh, SPO asesmen ulang risiko jatuh, dan SPO penanganan pasien jatuh dengan atau tanpa cidera.

\section{Kepatuhan Asesmen Risiko jatuh}

Kepatuhan perawat diartikan sejauh mana perilaku perawat sesuai dengan ketentuan yang diberikan oleh professional kesehatan (16). Kepatuhan perawat dalam melaksanakan asesmen risiko jatuh dapat dilihat dari seberapa sering perilaku perawat melaksanakan asesmen risiko jatuh tersebut baik asesmen awal maupun asesmen ulang. Adapun wawancara dengan informan adalah sebagai berikut:

“....Paling kepatuhannya itu mbak, patuh dan tidak patuh. Kadang kan mungkin pas sibuk atau pas lagi apa...mungkin dari skor 1 - 10 ada di 8....rata-rata hampir semua melakukan.... Untuk disini kita monitoringnya dua hari...." (I1)

"....Kalau asesmen awal saya yakin bisa terisi semua... tapi kalau untuk asesmen ulang.... Kita harus punya kebiasaan untuk diingatkan ya mbak...."(14)

"....Kalau asesmen awal sih selalu diisi ya mbak itu bisa lebih dari $80 \%$ lah.... Otomatis dilakukan dan selalu dilakukan.... Asesmen ulangnya itu kan lihat kondisi, terus juga risiko tinggi atau rendah dilihat dulu.... Monitoring nggak sedilakukan seperti asesmen awal...." (I5)

“....Untuk asesmen awal itu sebagian besar sudah diisi.... Kepatuhan itu memang paling utama.... Kepatuhan tergantung orangnya.... Monitoringnya itu tidak semua perawat patuh asesmen....
Perawat harus sadar diri kalau itu harus diisi... itu yang menerapkan susah masing-masing orang beda-beda...." (T2)

“....Untuk pengisiannya kayaknya masih kurang soalnya masih banyak yang kosong, kita cek itu masih banyak yang kosong...." (T4)

Berdasarkan wawancara yang telah dilakukan sebagian besar informan mengatakan bahwa asesmen awal risiko jatuh selalu dilakukandan diisi. Sedangkan untuk asesmen ulang risiko jatuh mereka mengatakan tidak semua perawat patuh untuk melaksanakan.

Pemahaman yang dimiliki terkait pelaksanaan asesmen risiko jatuh ternyata tidak membuat perawat selalu patuh untuk melaksanakannya walaupun sudah didukung dengan adanya motivasi dan sarana prasarana baik itu format asesmen maupun SPO risiko jatuh. Perawat menganggap masih banyak kendala-kendala yang dihadapi mulai dari kondisi pasien, keluarga pasien, dari diri perawat sendiri, serta dari kepemimpinan dan manajemen.

Kondisi pasien seperti pasien yang tidak stabil, pasien berontak, pasien mengamuk, adanya perubahan GCS, kejang membuat perawat untuk memilih menangani pasien terlebih dahulu.

Dari faktor keluarga ketika pasien di bawa ke ruangan rawat terkadang tidak ada keluarga yang menemani. Padahal untuk melakukan asesmen risiko jatuh membutuhkan wawancara dengan keluarga sehingga perawat menunggu sampai ada keluarga baru melaksanakan asesmen.

Dari faktor perawat sendiri seperti adanya kesibukan perawat, pasien penuh dan banyak pasien pengawasan, SDM yang kurang memadai, dan beban kerja yang tinggi membuat perawat lebih memilih untuk melakukan tindakan keperawatan lainnya dibanding melaksanakan asesmen risiko jatuh.

Dari kepemimpinan dan manajemen seperti kurangnya supervisi, serta tidak adanya reward dan punishment yang jelas membuat perawat tidak patuh terhadap pelaksanaan asesmen risiko jatuh.

Fakta di atas sesuai dengan beberapa penelitian terdahulu: Penelitian dari Elizabeth menyatakan bahwa masih ada perawat yang tidak patuh terhadap pelaksanaan SPO identifikasi risiko jatuh dengan skala morse dikarenakan beberapa faktor salah satu nya adalah kondisi pasien (17). Penelitian dari Rutami menunjukkan hasil bahwa adanya keluarga dapat mempercepat pengkajian keperawatan 
pasien, karena saat melakukan pengakjian perlu mewawancarai pasien dan keluarga tentang keadaan penyakit pasien (18). Penelitian Budiono menyatakan bahwa penilaian risiko jatuh dapat dilakukan dengan baik apabila terdapat kesiapan perawat seperti jumlah SDM dan ketrampilan, kebijakan dan prosedur yang diikuti dengan supervisi dan monitoring (13).

Boushon mengungkapkan kelalaian perawat dalam melaksanakan asesmen risiko jatuh yang berakibat pada tidak optimalnya pelaksanaan asesmen risiko jatuh tersebut dikarenakan oleh beberapa hal yang meliputi : tidak adanya standar prosedur untuk asesmen dan panduan manajemen risiko jatuh, tidak adanya pelatihan khusus, perawat tidak mampu mengidentifikasi pasien terhadap peningkatan risiko cedera akibat jatuh, perawat tidak mampu mengelola asesmen dan terlambat mengelola asesmen, perawat tidak mempunyai waktu yang konsisten untuk menilai kembali perubahan kondisi pasien, perawat gagal mengenali keterbatasan dari alat skrining risiko jatuh dan gagal mengkaji kembali kondisi pasien selama dirawat di rumah sakit (19).

Kepatuhan muncul sebagai bentuk dari sikap. Apabila perawat mempunyai sikap yang baik maka akan termotivasi untuk mematuhi tindakan yang berkaitan dengan pencegahan risiko jatuh $(20,21)$. Hariandja juga berpendapat bahwa motivasi merupakan kekuatan yang mendorong perawat untuk melakukan pekerjaan (22).

Terdapat dua faktor yang mempengaruhi adanya motivasi perawat yaitu faktor intrinsik dan ekstrinsik. Faktor intrinsik muncul sebagai faktor dari dalam diri yang dapat membangkitkan motivasi perawat misalkan kesadaran diri perawat dalam melaksanakan asesmen risiko jatuh. Sedangkan motivasi ekstrinsik berkaitan dengan faktor di luar individu seperti hubungan antar rekan kerja, hubungan dengan atasan, serta reward dan punishment (23).

Hubungan antar rekan kerja didapatkan apabila adanya kerjasama tim yang baik, saling mendukung satu sama lain dan saling melengkapi. Hubungan dengan atasan muncul ketika pemimpin memberikan pengarahan, bimbingan, memotivasi, dan memberikan dukungan (24). Kedua faktor tersebut harus didukung dengan adanya pemberian reward dan punishment yang jelas, karena apabila pemimpin tidak menerapkan reward dan punishment maka berdampak pada timbulnya demotivasi sehingga produktivitas kinerja perawat akan menurun (25). Penelitian yang dilakukan oleh Febriyanti menunjukkan hasil bahwa reward dan punishment lebih dominan berpengaruh secara langsung terhadap kinerja karyawan daripada motivasi kerja (26). Sejalan dengan penelitian yang dilakukan Febriyanti, penelitian Koencoro juga menunjukkan bahwa pemberian reward dan punishment berperngaruh terhadap kinerja karyawan (27). Adanya motivasi dan reward dan punishment yang diberikan oleh pimpinan diharapkan dapat merubah perilaku perawat untuk lebih mematuhi pekerjaannya.

\section{SIMPULAN DAN SARAN}

Adanya pemahaman terkait asesmen risiko jatuh tidak menjamin perawat untuk selalu patuh melaksanakan asesmen risiko jatuh pada pasien dikarenakan oleh adanya berbagai faktor penghambat diantaranya faktor kondisi pasien (pasien berontak; pasien tidak stabil; pasien ngamuk; perubahan GCS; kejang), faktor keluarga pasien (tidak adanya keluarga saat pasien masuk di ruangan rawat), faktor perawat itu sendiri (kesibukan perawat; pasien penuh dan banyak pasien pengawasan; SDM yang kurang memadai; dan beban kerja yang tinggi), dan faktor kepemimpinan dan manajemen (kurangnya supervisi; tidak adanya reward dan punishment yang jelas).

Diharapkan adanya kerjasama antara manajemen rumah sakit, pokja pencegahan risiko jatuh, serta kepala ruang untuk senantiasa melakukan supervisi dan monitoring evaluasi terkait pelaksanaan asesmen risiko jatuh yang dilakukan secara berkala disertai dengan pemberian reward dan punishment yang jelas.

\section{RUJUKAN}

1. Joint Commission International. Standar Akreditasi Rumah Sakit. 2011.

2. Komite Akreditsi Rumah Sakit. Instrumen Akreditasi Rumah Sakit Versi 2012. Jakarta; 2012.

3. Joint Commission International. Sentinel Alert Event [Internet]. 2015;(55). Available from: www. joincommission.org

4. AHRQ. Fall and Injury Prevention. In: Patient Safety and Quality. An Evidence-Based Handbook for Nurses [Internet]. 2008;08-0043. Available from: www.ahrq.gov/qual/nurseshdbk/docs/ CurrieL_FIP.pdf.

5. National Patient Safety Agency. Slips, Trips and Falls in Hospital. In 2007. Available from: www. nrls.npsa.nhs.uk/resources/ 
6. PERSI. Seminar Keselamatan Pasien. Jakarta; 2012.

7. Diah FP. Strategi Meningkatkan Perilaku Caring Perawat dalam Mutu Pelayanan Keperawatan. J Manaj Keperawatan. 2015;3(1):1-6.

8. Yulia S. Pengaruh Pelatihan Keselamatan Pasien Terhadap Pemahaman Perawat Pelaksana Mengenai Penerapan Keselamatan Pasien di RS Tugu Ibu Depok. Universitas Indonesia; 2010.

9. Notoatmodjo. Promosi Kesehatan dan IImu perilaku. Jakarta: PT Rineka Cipta; 2007.

10. Harten-Krouwel, Marieke S, Marielle Emmelot-Vonk, Ruth Pel-Littel. Development and Feasibility of Falls Prevention Advice. J Clin Nurs. 2011;20:2761-76.

11. Kozier-Erbs, Audrey B, Shirlee S, Geralyn F. Fundamental of Nursing Consepts, Process, and Practice. 10th ed. USA: Pearson Education Inc; 2016.

12. Sizewise. Understanding Fall Risk, Prevention, and Protection. USA: Kansas; 2007.

13. Budiono S. Pelaksanaan Program Manajemen Pasien dengan Risiko Jatuh di Rumah Sakit. J Kedokt Brawijaya. 2014;28(1).

14. Budioro B. Pengantar Pendidikan (Penyuluhan) Kesehatan Masyarakat. 2nd ed. Semarang: Badan Penerbit Universitas Diponegoro; 2007.

15. Maulana H. Promosi Kesehatan. Jakarta: EGC; 2009.

16. Niven Neil. Psikologi Kesehatan: Pengantar Untuk Perawat Dan Profesional. Jakarta: EGC; 2008.

17. Setyarini E. Pelaksanaan Standar Prosedur Operasional: Identifikasi Resiko Pasien Jatuh dengan Menggunakan Skala Jatuh Morse di Rumah Sakit "A" Bandung. Artik J. 2010;

18. Rutami. Pelaksanaan Proses Pengkajian Keperawatan di Ruang Rawat Inap RSUP $\mathrm{H}$. Adam Malik Medan. Universitas Sumatera Utara; 2012.

19. Boushon B et al. Transforming Care at the Bedside How-to Guide: Reducing Patient Injuries from Falls. Cambridge: Institute for Health Care Improvement; 2008.

20. Gibson J et al. Organisasi: Perilaku, Struktur, dan Proses. Jakarta: Erlangga; 2006.

21. Sarwono. Manajemen Sumber Daya Manusia di Rumah Sakit Suatu Pendekatan Sistem. Jakarta: EGC; 2011.

22. Hariandja M. Manajemen Sumber Daya Manusia. Jakarta: Grasindo; 2009.

23. Marquis \& Huston. Kepemimpinan dan Manajemen Keperawatan: Teori dan Aplikasi. Empat. Jakarta: EGC; 2010.

24. Hasibuan MSP. Organisasi dan Motivasi Dasar Peningkatan Produktivitas. Jakarta: PT. Bumi Aksara; 2008.

25. Michelle S. Habbit : Delapan Kebiasaan yang Mengubah Nasib Anda. Jakarta: Gramedia Pustaka Utama; 2009.

26. Silfia F. Pengaruh Reward dan Punishment terhadap Motivasi Kerja serta Dampaknya terhadap Kinerja. J Adm Bisnis. 2014;12(1):1-9.

27. Koencoro D. Pengaruh Reward dan Punishment terhadap Kinerja. Universitas Brawijaya; 2012. 